\title{
Integrated effects of poultry manure and chemical fertilizer on the growth, leaf yield and stevioside content of stevia
}

\author{
M. M. Zaman, M. A. H. Chowdhury ${ }^{1^{*}}$ and Tanzin Chowdhury ${ }^{2}$ \\ Soil Resources Development Institute, Farmgate, Dhaka, ${ }^{1}$ Department of Agricultural Chemistry and ${ }^{2}$ Department of \\ Agronomy, Bangladesh Agricultural University, Mymensingh-2202, Bangladesh, *E-mail: akhterbau11@gmail.com
}

\begin{abstract}
Stevia is important for its leaves which are used as non calorie sweetener and also in many therapeutic applications including diabetes. The present investigation was carried out in the net house of the Department of Agricultural Chemistry, Bangladesh Agricultural University, Mymensingh to investigate the integrated effects of poultry manure (PM) and chemical fertilizer (CF) on the growth, leaf biomass yield and stevioside content of stevia grown in two contrasting soils (acid and non-calcareous) of Bangladesh. Six combinations of $P M$ and $C F \quad v i z$. $P M M_{0}+C F_{0}$, $\mathrm{PM}_{0}+\mathrm{CF}_{100}, \mathrm{PM}_{3}+\mathrm{CF}_{50}, \mathrm{PM}_{3}+\mathrm{CF}_{75}, \mathrm{PM}_{5}+\mathrm{CF}_{50}, \mathrm{PM}_{5}+\mathrm{CF}_{75}$ were used. The study revealed that $\mathrm{PM}$ along with different percentages of chemical fertilizers exerted significant influence on the growth, leaf yield and stevioside content of stevia. The highest values of all the parameters except stevioside were found from the plant receiving PM @ $3 \mathrm{t}$ ha ${ }^{-1}$ along with $75 \%$ CF. The leaf biomass yield was $1088 \%$ and $867 \%$ higher in acid soil and non-calcareous soil, respectively, over control. Stevioside content was increased with increasing the levels of PM up to $5 \mathrm{t} \mathrm{ha}^{-1}$ and also with the advancement of growth period from 30 to 60 days after planting. The highest amount of stevioside (10.45\%) was detected in the leaves of the plant that received PM @ $5 \mathrm{t} \mathrm{ha}^{-1}$ along with $75 \%$ CF at 60 DAP in acid soil and it was $9.11 \%$ in non-calcareous soil at the same period. The lowest values of all the parameters including stevioside content were obtained from the plant which received neither PM nor CF. Considering the overall performance, farmers may be advised to cultivate stevia in acid soil applying PM @ $3 \mathrm{t} \mathrm{ha}^{-1}$ along with 75\% chemical fertilizer to boost up the production of stevia under the agro-climatic condition of the study area in the context of Bangladesh.
\end{abstract}

Keywords: Stevia, Poultry manure, Chemical fertilizer, Leaf yield, Stevioside content, Acid and noncalcareous soil

\section{Introduction}

Stevia has been introduced as a crop in a number of countries and has become a popular natural source of high potency sweetener and dietary supplement. Cultivation of stevia crop made significant impact on the economy of many countries including Brazil, Korea, Mexico, United States, Indonesia, Tanzania and Canada (Lee et al., 1979; Donalisio et al., 1982; Goeinadi, 1983; Shock, 1982; Brandle and Rosa, 1992). Currently stevia production is concentrated in China and the major market is Japan (Kinghorn and Soejarto, 1985). Dry leaves are the economic part of stevia plant. The leaves synthesize zero-calorie entkaurene diterpene glycosides (steviosides and rebuadiosides). The major sweet compound stevioside as a dietary supplement for human subjects are manifold. It might be used as an alternative source to the synthetic sweetening agents like saccharine, aspertame, asulfam- $\mathrm{K}$ that are available in the market to the diet conscious consumers and diabetics (Aladakatti et al, 2012).

Stevia being a calorie free herb offers a solution for complex diabetic problems and obesity. The worldwide demand for the natural sweeteners is expected to increase in the years to come. Kinghorn and Soejarto (1985) opined that stevioside is a white amorphous powder present in leaf and stem tissue which was seriously considered as a cane sugar substitute. Literature survey revealed active constituents especially stevioside content in stevia plant greatly depends on the package of practices for the cultivation of stevia and adoption of modern agro- techniques and water management (Nepovim et al., 1998). Stevioside content varies from 4-20\% depending on cultivar, soil, organic and inorganic fertilization and other environmental factors (Geuns, 2004). In view of the above fact, cultivation of stevia is gradually coming into focus in Bangladesh agriculture due to having no optimum agronomic management practices (Hasan, 2008 and Khan, 2014). 
Some preliminary experiments on morphological and physiological parameters have been conducted in Bangladesh Sugarcrop Research Institute (BSRI). Recently brac has started pot and/or field experiment in small scale. Though brac, BSRI and Proshika have developed method for in vitro production of stevia seedlings, no study has yet been conducted to quantify the content of stevioside from stevia leaves in Bangladesh. Long term sustainable production of crops cannot be maintained by using chemical fertilizers alone and similarly, it is not possible to obtain higher crop yield by using only organic manure (Bair, 2000). Nambiar (2000) viewed that integrated use of manure and fertilizers would be quite promising not only in providing greater stability in production, but also in maintaining higher soil fertility status.

The problem of nutrient deficiencies as well as nutrient mining caused by intensive cropping and nutrient imbalance can be minimized by judicious application of chemical fertilizers in combination with organic manures. Poultry industry in Bangladesh has been increasing dramatically over last few decades and poultry manure (PM) has long been recognized as perhaps the most desirable animal manures because of its high nutrient content and ease of decomposition. Addition of PM to the crop field could be a very good option considering its availability in the context of Bangladesh for maintaining soil fertility and productivity. It is essential to develop an appropriate technique of cultivation and quantify the stevioside content to boost up the production of stevia in the country. The present research was, therefore, considered to investigate the integrated effects of poultry manure and chemical fertilizers on the growth, leaf biomass yield and stevioside content of stevia.

\section{Materials and Methods}

A pot experiment was conducted at the net house of the Department of Agricultural Chemistry, Bangladesh Agricultural University, Mymensingh during March to May, 2011 to investigate the integrated effects of poultry manure (PM) and chemical fertilizer (CF) on the growth, leaf biomass yield and stevioside content of stevia. Two contrasting soils (acid and non-calcareous) were used. The physical and chemical properties of the soils can be seen from Zaman et al. (2015). Approximately $40 \mathrm{~kg}$ soils from each location (Madhupur for acid soil and BAU farm for non-calcareous soil) were collected from $0-15 \mathrm{~cm}$ depth of selected fallow land for the experiment. The samples were made free from plant residues and other extraneous materials, air dried, ground and sieved through a $2 \mathrm{~mm}$ sieve. Five hundred gram $(500 \mathrm{~g})$ sieved soil from each source was preserved in a polythene bag and the physical and chemical properties were analyzed following standard procedure (Page et al. 1982).

Eight $\mathrm{kg}$ processed soil was taken in each earthen pot of $23 \mathrm{~cm}$ in height with $30 \mathrm{~cm}$ diameter at top and $18 \mathrm{~cm}$ at bottom leaving $3 \mathrm{~cm}$ from the top. In vitro produced 45 day old stevia seedlings (Stevia rebaudiana Bertoni) were collected from brac Biotechnology Laboratory, Joydebpur, Gazipur and used for the experiment. One stevia seedling was planted in each pot during $1^{\text {st }}$ week of March, 2011. Nitrogen, $P$, K, S, Zn and B were applied as basal doses @ 250, 100, 200, 30, 3 and $1 \mathrm{~kg} \mathrm{ha}^{-1}$ from TSP, MoP, gypsum, zinc sulphate and boric acid, respectively as chemical fertilizer (CF). Sulphur rate was adjusted from both gypsum and zinc sulphate. Following treatment combinations of PM and CF were used for the study.

\begin{tabular}{ll}
\hline Treatment symbol & $\begin{array}{c}\text { Rate of PM }\left(\mathrm{t} \mathrm{ha}^{-1}\right) \\
\text { and CF }(\%)\end{array}$ \\
\hline $\mathrm{PM}_{0}+\mathrm{CF}_{0}$ & $\mathrm{PM} 0$ plus CF 0 \\
$\mathrm{PM}_{0}+\mathrm{CF}_{100}$ & $\mathrm{PM} 0$ plus CF 100 \\
$\mathrm{PM}_{3}+\mathrm{CF}_{50}$ & $\mathrm{PM} 3$ plus CF 50 \\
$\mathrm{PM}_{3}+\mathrm{CF}_{75}$ & $\mathrm{PM} 3$ plus CF 75 \\
$\mathrm{PM}_{5}+\mathrm{CF}_{50}$ & $\mathrm{PM} 5$ plus CF 50 \\
$\mathrm{PM}_{5}+\mathrm{CF}_{75}$ & $\mathrm{PM} 5$ plus CF 75 \\
\hline
\end{tabular}


The experiment was laid out in completely randomized design with three replications. Total number of pots was 36 (6 treatment $\times 2$ soil $\times 3$ replication). Intercultural operations like irrigation, soil loosening, weeding, insect pest control, removal of flowers etc. were done as and when necessary. Data were collected at 15, 30, 45 and 60 days after planting (DAP). The crop was destructively harvested at 60 DAP. After harvesting the crop, leaf samples were separated, cleaned and dried at $60^{\circ} \mathrm{C}$ for 72 hours, weighed, ground and stored. Plant height, branches plant ${ }^{-1}$, leaves plant $^{-1}$, leaf area plant ${ }^{-1}$, dry leaf weight of stevia leaves were studied. Stevioside content of stevia leaf was determined following the method of Kolb et. al.(2001). The results obtained were subjected to statistical analysis using standard method (Steel et al., 1997). The differences among the treatment means were compared by using Duncan Multiple Range test (Gomez and Gomez, 1984).

\section{Results}

The integrated effects of PM and CF on the growth, leaf biomass yield and stevioside content of stevia are described under the following heads.

\section{Plant height}

The application of PM and CF in different combinations had a significant effect on the plant height of stevia at different DAP in both the studied soils (Table 1). Plant height was gradually increased with time of growth period.

Table 1. Integrated effects of poultry manure and chemical fertilizer on the plant height of stevia at various DAP*

\begin{tabular}{|c|c|c|c|c|c|c|c|c|c|c|}
\hline \multirow{3}{*}{$\begin{array}{c}\text { PM and CF } \\
\text { level }\end{array}$} & \multicolumn{10}{|c|}{ Plant height $(\mathrm{cm})$} \\
\hline & \multicolumn{5}{|c|}{ Acid soil } & \multicolumn{5}{|c|}{ Non-calcareous soil } \\
\hline & 0 & 15 & 30 & 45 & 60 & 0 & 15 & 30 & 45 & 60 \\
\hline$\overline{\mathrm{PM}_{0} \mathrm{CF}_{0}}$ & $9.0 \mathrm{~b}$ & $15.0 \mathrm{c}$ & $27.3 b$ & $43.3 c$ & $55.3 c$ & $9.0 b$ & $16.3 \mathrm{c}$ & $36.3 b$ & $58.3 b$ & $64.0 c$ \\
\hline $\mathrm{CF}_{100} \mathrm{PM}_{0}$ & 10.0ab & $18.0 b$ & $40.0 \mathrm{a}$ & $62.0 \mathrm{a}$ & $77.7 \mathrm{a}$ & 10.0ab & 21.0ab & $38.7 b$ & $62.0 \mathrm{~b}$ & $81.7 b$ \\
\hline $\mathrm{PM}_{3}+\mathrm{CF}_{50}$ & $10.0 \mathrm{ab}$ & $15.0 c$ & $34.0 \mathrm{ab}$ & $56.3 b$ & 75.0ab & $10.0 a b$ & $20.0 b$ & $37.3 b$ & $61.7 \mathrm{~b}$ & $78.3 \mathrm{bc}$ \\
\hline $\mathrm{PM}_{3}+\mathrm{CF}_{75}$ & 10.0ab & $20.3 a$ & $40.7 a$ & $65.7 a$ & $83.0 a$ & $10.3 a$ & $24.0 \mathrm{a}$ & $50.7 a$ & $78.0 \mathrm{a}$ & $94.7 a$ \\
\hline $\mathrm{PM}_{5}+\mathrm{CF}_{50}$ & $9.0 b$ & $17.3 b$ & $37.7 \mathrm{a}$ & $61.3 a$ & $72.7 b$ & $9.0 b$ & $22.7 a b$ & $48.0 \mathrm{a}$ & $73.0 \mathrm{a}$ & $76.7 \mathrm{bc}$ \\
\hline $\mathrm{PM}_{5}+\mathrm{CF}_{75}$ & $10.3 a$ & $20.0 \mathrm{a}$ & 36.0ab & 59.3ab & $69.7 \mathrm{bc}$ & $10.3 a$ & 22.0ab & $39.3 b$ & $62.0 \mathrm{~b}$ & 73.3bc \\
\hline $\mathrm{CV}(\%)$ & 0.9 & 1.2 & 1.2 & 1.2 & 1.2 & 0.9 & 1.1 & 1.3 & 1.1 & 1.2 \\
\hline LSD $_{0.05}$ & 1.1 & 1.9 & 3.9 & 6.1 & 7.6 & 1.2 & 2.1 & 4.5 & 6.8 & 8.1 \\
\hline
\end{tabular}

*DAP $=$ Days after planting, $C V=$ Coefficient of variance, $L S D=$ Least significant difference,

The tallest plant $(83 \mathrm{~cm}$ in acid soil and $94.7 \mathrm{~cm}$ in non-calcareous soil) was recorded from the treatment $\mathrm{PM}_{3} \mathrm{CF}_{75}$ at 60 DAP in both soils under study which was identical with all other combinations of PM and $\mathrm{CF}$ except control in acid soil at the same DAP but significantly different from other treatment combinations of PM and CF in non-calcareous soil. The shortest plant $(55.3 \mathrm{~cm}$ in acid soil and $64 \mathrm{~cm}$ in non-calcareous soil) was noticed in control treatment $\left(\mathrm{PM}_{0} \mathrm{CF}_{0}\right)$.

\section{Branch number}

Significant variation on the number of branches plant ${ }^{-1}$ was observed due to the application of different combinations of PM and CF at various DAP (Table 2). Branch numbers increased slowly up to 15 DAP and then increased rapidly up to 60 DAP.

The highest number of branches plant ${ }^{-1}$ (13 and 15.3 in acid and non-calcareous soil, respectively) was observed in the plant fertilized with PM @ $3 \mathrm{t} \mathrm{ha}^{-1}$ in combination with $75 \%$ CF where as the lowest branch number was observed throughout the growth period in the control treatment. The second highest number of branches (11 in acid soil and 10.3 in non-calcareous soil) was counted from $\mathrm{PM}_{5} \mathrm{CF}_{50}$. 
Table 2. Integrated effects of poultry manure and chemical fertilizer on the branch number of stevia at various DAP*

\begin{tabular}{|c|c|c|c|c|c|c|c|c|c|c|}
\hline \multirow{3}{*}{$\begin{array}{c}\text { PM and CF } \\
\text { level }\end{array}$} & \multicolumn{10}{|c|}{ Branches Plant $^{-1}$ (No.) } \\
\hline & \multicolumn{5}{|c|}{ Acid soil } & \multicolumn{5}{|c|}{ Non-calcareous soil } \\
\hline & 0 & 15 & 30 & 45 & 60 & 0 & 15 & 30 & 45 & 60 \\
\hline $\mathrm{PM}_{0} \mathrm{CF}_{0}$ & 1.0 & $1.3 b$ & $1.7 \mathrm{c}$ & $2.0 \mathrm{c}$ & $2.7 \mathrm{c}$ & 1.0 & $1.3 \mathrm{c}$ & $2.0 \mathrm{c}$ & $2.3 \mathrm{c}$ & $3.0 \mathrm{c}$ \\
\hline $\mathrm{CF}_{100} \mathrm{PM}_{0}$ & 1.0 & $2.0 \mathrm{~b}$ & $5.0 \mathrm{a}$ & $7.3 a$ & $9.0 b$ & 1.0 & $2.0 \mathrm{~b}$ & $5.0 a b$ & $7.0 \mathrm{~b}$ & $9.7 b$ \\
\hline $\mathrm{PM}_{3}+\mathrm{CF}_{50}$ & 1.0 & $1.7 \mathrm{~b}$ & 4.7ab & 6.0ab & $7.7 b$ & 1.0 & $1.7 \mathrm{bc}$ & $4.3 b$ & $6.0 \mathrm{~b}$ & $8.0 \mathrm{bc}$ \\
\hline $\mathrm{PM}_{3}+\mathrm{CF}_{75}$ & 1.0 & $3.0 \mathrm{a}$ & $6.0 \mathrm{a}$ & $8.0 a$ & $13.0 \mathrm{a}$ & 1.0 & $4.0 \mathrm{a}$ & $7.0 \mathrm{a}$ & $10.0 \mathrm{a}$ & $15.3 a$ \\
\hline $\mathrm{PM}_{5}+\mathrm{CF}_{50}$ & 1.0 & $2.3 a$ & $3.3 b$ & 6.0ab & 11.0ab & 1.0 & 3.3ab & $6.3 a$ & $8.0 \mathrm{a}$ & $10.3 b$ \\
\hline $\mathrm{PM}_{5}+\mathrm{CF}_{75}$ & 1.0 & $2.0 \mathrm{~b}$ & $3.0 \mathrm{bc}$ & $5.0 \mathrm{~b}$ & $9.0 \mathrm{~b}$ & 1.0 & $2.0 \mathrm{~b}$ & $5.0 a b$ & 7.7ab & $9.0 \mathrm{~b}$ \\
\hline $\mathrm{CV}(\%)$ & 0.0 & 3.3 & 3.6 & 3.6 & 3.4 & 0.0 & 3.9 & 3.6 & 3.4 & 3.6 \\
\hline $\mathrm{LSD}_{0.05}$ & 0.0 & 0.8 & 1.2 & 2.2 & 2.1 & 0.0 & 0.8 & 2.0 & 2.1 & 2.3 \\
\hline
\end{tabular}

${ }^{*} \mathrm{DAP}=$ Days after planting, $\mathrm{CV}=$ Coefficient of variance, $\mathrm{LSD}=$ Least significant difference

\section{Leaf number}

Leaf number differed significantly due to the application of different levels of PM and CF at various DAP (Table 3). A rapid and tremendous increase in leaf number was observed in the plant fertilized with PM @ $3 \mathrm{t} \mathrm{ha}^{-1}$ along with $75 \% \mathrm{CF}$ in both soils. The highest number of leaves plant ${ }^{-1}$ was counted from the plant treated with $\mathrm{PM}_{3} \mathrm{CF}_{75}$ which was significantly different from other treatment combinations. In contrast, the lowest leaf number was observed in the plant receiving neither $\mathrm{PM}$ nor CF. Plants fertilized with $\mathrm{PM}_{0} \mathrm{CF}_{100}, \mathrm{PM}_{3} \mathrm{CF}_{50}, \mathrm{PM}_{5} \mathrm{CF}_{50}, \mathrm{PM}_{5} \mathrm{CF}_{75}$ produced identical number of leaves plant ${ }^{-1}$ in non-calcareous soil. Except control, among other treatment combinations, the lowest number of leaves was counted from the plant fertilized with $\mathrm{PM}_{5} \mathrm{CF}_{75}$ which was significantly different from other treatments in acid soil.

Table 3. Integrated effects of poultry manure and chemical fertilizer on the leaf number of stevia at various DAP*

\begin{tabular}{|c|c|c|c|c|c|c|c|c|c|c|}
\hline \multirow{3}{*}{ PM and CF level } & \multicolumn{10}{|c|}{ Leaves Plant $^{-1}$ (No.) } \\
\hline & \multicolumn{5}{|c|}{ Acid soil } & \multicolumn{5}{|c|}{ Non-calcareous soil } \\
\hline & 0 & 15 & 30 & 45 & 60 & 0 & 15 & 30 & 45 & 60 \\
\hline $\mathrm{PM}_{0} \mathrm{CF}_{0}$ & 4.3 & $8.0 \mathrm{e}$ & $22.0 d$ & $25.7 d$ & $27.7 d$ & 4.3 & $11.3 e$ & $26.3 c$ & $38.7 d$ & $46.3 d$ \\
\hline $\mathrm{CF}_{100} \mathrm{PM}_{0}$ & 5.0 & $26.0 \mathrm{~b}$ & $78.0 \mathrm{~b}$ & 189.0b & 309.0ab & 5.0 & $31.7 b$ & $89.3 b$ & $213.0 b$ & $359.0 b$ \\
\hline $\mathrm{PM}_{3}+\mathrm{CF}_{50}$ & 4.7 & $20.0 \mathrm{c}$ & $60.3 c$ & $156.0 \mathrm{c}$ & $280.0 b$ & 4.7 & $25.3 c$ & $82.3 b$ & 199.0bc & $320.0 \mathrm{bc}$ \\
\hline $\mathrm{PM}_{3}+\mathrm{CF}_{75}$ & 4.7 & $35.0 \mathrm{a}$ & $91.0 \mathrm{a}$ & $256.0 a$ & $330.0 a$ & 5.0 & $39.3 a$ & $121.7 a$ & $309.0 a$ & 448.0a \\
\hline $\mathrm{PM}_{5}+\mathrm{CF}_{50}$ & 4.7 & $17.7 \mathrm{c}$ & $61.3 \mathrm{c}$ & $165.7 \mathrm{bc}$ & 288.0b & 4.7 & $24.3 c$ & $97.0 \mathrm{~b}$ & 191.0c & $346.0 b$ \\
\hline $\mathrm{PM}_{5}+\mathrm{CF}_{75}$ & 5.0 & $11.7 \mathrm{~d}$ & $55.0 \mathrm{c}$ & $157.3 \mathrm{c}$ & 207.0c & 4.3 & $15.0 \mathrm{~d}$ & $86.0 \mathrm{~b}$ & 178.0c & 298.0c \\
\hline $\mathrm{CV}(\%)$ & 2.3 & 3.8 & 2.9 & 3.6 & 3.5 & 2.3 & 3.2 & 2.9 & 3.5 & 3.4 \\
\hline LSD $_{0.05}$ & 1.6 & 2.6 & 6.6 & 17.1 & 26.4 & 1.6 & 3.0 & 8.8 & 20.4 & 32.0 \\
\hline
\end{tabular}

*DAP $=$ Days after planting, $C V=$ Coefficient of variance, $L S D=$ Least significant difference

Leaf number was increased by 179-302 in acid soil and 252-402 in non-calcareous soil over control irrespective of treatments.

\section{Leaf area}

The application of PM and CF in different combinations had a significant effect on the leaf area of stevia at 60 DAP (Table 4). The highest leaf area plant ${ }^{-1}\left(2307 \mathrm{~cm}^{2}\right.$ in acid soil and $4115 \mathrm{~cm}^{2}$ in non-calcareous soil) was measured from the plant fertilized with $\mathrm{PM}_{3} \mathrm{CF}_{75}$ in both soils which was identical with all other combinations of $\mathrm{PM}$ and $\mathrm{CF}$ except control in non-calcareous soil at the same DAP but significantly different from $\mathrm{PM}_{5} \mathrm{CF}_{75}$ and control in acid soil. The lowest leaf area plant ${ }^{-1}\left(133 \mathrm{~cm}^{2}\right.$ in acid soil and 246 $\mathrm{cm}^{2}$ in non-calcareous soil) was noticed in the plant grown in control treatment $\left(\mathrm{PM}_{0} \mathrm{CF}_{0}\right)$. 


\section{Dry weight}

The dry weight of stevia leaves plant ${ }^{-1}$ at harvest varied significantly due the application of different levels of PM and CF (Table 4). Results revealed that dry weight progressively increased with increasing levels of $\mathrm{PM}$ and $\mathrm{CF}$ application up to $\mathrm{PM}_{3} \mathrm{CF}_{75}$ in both soils and then declined with further addition $\left(\mathrm{PM}_{5} \mathrm{CF}_{50}\right.$ and $\left.\mathrm{PM}_{5} \mathrm{CF}_{75}\right)$. The highest dry weight plant ${ }^{-1}(9.98 \mathrm{~g}$ in acid soil and $13.55 \mathrm{~g}$ in non-calcareous soil) at harvest was measured from the plant receiving $\mathrm{PM}_{3} \mathrm{CF}_{75}$ which was significantly higher than other levels of $\mathrm{PM}$ and $\mathrm{CF}$ in non-calcareous soil but identical with $\mathrm{PM}_{0} \mathrm{CF}_{100}$ and $\mathrm{PM}_{5} \mathrm{CF}_{50}$ in acid soil.

Table 4. Integrated effects of poultry manure and chemical fertilizer on leaf area, dry weight and yield increase of stevia leaves over control at harvest

\begin{tabular}{l|c|c|c|c|c|c}
\hline \multirow{2}{*}{$\begin{array}{l}\mathrm{PM} \text { and CF } \\
\text { level }\end{array}$} & \multicolumn{2}{|c|}{$\begin{array}{c}\text { Leaf area plant } \\
\left(\mathrm{cm}^{2}\right)\end{array}$} & \multicolumn{2}{c|}{$\begin{array}{c}\text { Leaf dry weight } \\
(\mathrm{g} \text { plant }\end{array}$} & \multicolumn{2}{c}{$\begin{array}{c}\text { Yield increase over } \\
\text { control (\%) }\end{array}$} \\
\cline { 2 - 7 } & $\begin{array}{c}\text { Acid } \\
\text { soil }\end{array}$ & $\begin{array}{c}\text { Non-calcar eous } \\
\text { soil }\end{array}$ & $\begin{array}{c}\text { Acid } \\
\text { soil }\end{array}$ & $\begin{array}{c}\text { Non-calcareous } \\
\text { soil }\end{array}$ & $\begin{array}{c}\text { Acid } \\
\text { soil }\end{array}$ & $\begin{array}{c}\text { Non-calcareous } \\
\text { soil }\end{array}$ \\
\hline $\mathrm{PM}_{0} \mathrm{CF}_{0}$ & $133 \mathrm{c}$ & $246 \mathrm{c}$ & $0.84 \mathrm{~d}$ & $1.40 \mathrm{~d}$ & - & - \\
$\mathrm{PM}_{0} \mathrm{CF}_{100}$ & $2076 \mathrm{ab}$ & $2471 \mathrm{~b}$ & $9.35 \mathrm{a}$ & $10.86 \mathrm{~b}$ & 1013 & 675 \\
$\mathrm{PM}_{3}+\mathrm{CF}_{50}$ & $1589 \mathrm{~b}$ & $2267 \mathrm{~b}$ & $8.47 \mathrm{~b}$ & $9.68 \mathrm{c}$ & 908 & 591 \\
$\mathrm{PM}_{3}+\mathrm{CF}_{75}$ & $2307 \mathrm{a}$ & $4115 \mathrm{a}$ & $9.98 \mathrm{a}$ & $13.55 \mathrm{a}$ & 1088 & 867 \\
$\mathrm{PM}_{5}+\mathrm{CF}_{50}$ & $1661 \mathrm{~b}$ & $2399 \mathrm{~b}$ & $8.71 \mathrm{~b}$ & $10.47 \mathrm{~b}$ & 937 & 648 \\
$\mathrm{PM}_{5}+\mathrm{CF}_{75}$ & $1352 \mathrm{~b}$ & $2558 \mathrm{~b}$ & $6.26 \mathrm{c}$ & $9.01 \mathrm{c}$ & 645 & 543 \\
\hline $\mathrm{CV}_{5}(\%)$ & 4 & 4 & 3.52 & 3.38 & - & - \\
\hline $\mathrm{LSD}_{0.05}$ & 445 & 460 & 0.81 & 1.01 & - & - \\
\hline
\end{tabular}

$\mathrm{CV}=$ Coefficient of variance, $\mathrm{LSD}=$ Least significant difference

Second highest values $(9.35 \mathrm{~g}$ in acid soil and $10.86 \mathrm{~g}$ in non-calcareous soil) were obtained from $\mathrm{PM}_{0} \mathrm{CF}_{100}$. The leaf yield was $41 \%$ higher in respect of combined application of PM @ $3 \mathrm{t} \mathrm{ha}^{-1}$ and CF $75 \%$ than that of the sole application of PM maintaining the equal rate. The lowest values were obtained from the control treatment $\left(\mathrm{PM}_{0} \mathrm{CF}_{0}\right)$. Dry weight increased by 645 to $1088 \%$ in acid soil and 543 to $867 \%$ in non-calcareous soil over control across the treatments.

\section{Stevioside content}

There was a significant effect of different levels of PM and CF on the stevioside contents of stevia leaf (Table 5). Stevioside content of the leaf was gradually increased with increasing the levels of PM irrespective of soils used.

Table 5. Integrated effects of poultry manure and chemical fertilizer on the stevioside contents of stevia leaf at various DAP

\begin{tabular}{|c|c|c|c|c|c|c|}
\hline \multirow{3}{*}{ PM and CF level } & \multicolumn{6}{|c|}{ Stevioside content (\%) } \\
\hline & \multicolumn{3}{|c|}{ Acid soil } & \multicolumn{3}{|c|}{ Non-calcareous soil } \\
\hline & 30 DAP & 45 DAP & 60 DAP & 30 DAP & $45 \mathrm{DAP}$ & 60 DAP \\
\hline $\mathrm{PM}_{0} \mathrm{CF}_{0}$ & $2.96 \mathrm{~d}$ & $3.72 \mathrm{e}$ & $5.22 \mathrm{e}$ & $2.49 \mathrm{e}$ & $3.25 \mathrm{e}$ & $5.10 c$ \\
\hline $\mathrm{PM}_{0} \mathrm{CF}_{100}$ & $3.28 d$ & $4.45 d$ & $5.98 d$ & $3.00 \mathrm{~d}$ & $3.97 d$ & $5.63 c$ \\
\hline $\mathrm{PM}_{3}+\mathrm{CF}_{50}$ & $4.62 c$ & $5.21 \mathrm{c}$ & 7.37c & $4.12 \mathrm{c}$ & $5.00 c$ & $6.82 b$ \\
\hline $\mathrm{PM}_{3}+\mathrm{CF}_{75}$ & $4.93 c$ & $6.19 b$ & $8.63 b$ & $4.36 c$ & $5.72 b$ & $7.14 b$ \\
\hline $\mathrm{PM}_{5}+\mathrm{CF}_{50}$ & $5.75 b$ & $6.36 \mathrm{~b}$ & $9.14 b$ & $5.27 \mathrm{~b}$ & $6.04 b$ & $8.37 \mathrm{a}$ \\
\hline $\mathrm{PM}_{5}+\mathrm{CF}_{75}$ & $6.24 a$ & $8.25 a$ & $10.45 a$ & $5.92 a$ & $7.82 \mathrm{a}$ & $9.11 \mathrm{a}$ \\
\hline $\mathrm{CV}(\%)$ & 2.19 & 2.19 & 1.99 & 2.39 & 2.36 & 1.75 \\
\hline $\mathrm{LSD}_{0.05}$ & 0.48 & 0.60 & 0.82 & 0.45 & 0.55 & 0.74 \\
\hline
\end{tabular}

DAP = Days after planting, CV = Coefficient of variance, $L S D=$ Least significant difference,

The highest stevioside content $(10.45 \%$ in acid soil and $9.11 \%$ in non-calcareous soil) was found in the leaves of the plant fertilized with PM @ $5 \mathrm{t} \mathrm{ha}^{-1}$ along with $75 \%$ CF which was at par with the stevioside contents of the plants receiving PM @ $5 \mathrm{t} \mathrm{ha}^{-1}$ and $50 \%$ CF in both soils. The lowest stevioside content was obtained from the plant fertilized with neither PM nor CF. Stevioside contents were also significantly 
increased with the advancement of growth period from 30 to 60 DAP irrespective of treatments and soils used. Leaf stevioside content of the PM amended soil was much higher than the plants grown in CF amended soil. Plants grown in acid soil synthesized more stevioside compared to the plants of noncalcareous soil irrespective of the treatments employed.

\section{Discussion}

\section{Leaf yield and yield attributes}

The highest plant height was observed in $\mathrm{PM}_{3}+\mathrm{CF}_{75}$ treatment at harvesting time followed by the treatment $\mathrm{PM}_{0}+\mathrm{CF}_{100}, \mathrm{PM}_{3}+\mathrm{CF}_{50}, \mathrm{PM}_{5}+\mathrm{CF}_{50}, \mathrm{PM}_{5}+\mathrm{CF}_{75}$ and $\mathrm{PM}_{0}+\mathrm{CF}_{0}$ treatments, respectively. The reasons of obtaining higher plant height might be due to the combined application of chemical fertilizer and poultry manure. On the other hand, the lowest plant height of the control treatment might be due to the application of neither organic nor chemical fertilizers. Kumar et al. (2013) noticed that combined application of chemical fertilizer and poultry manure increased the plant height of stevia. The number of branches plant ${ }^{-1}$ was gradually increased under all treatments. The growth was much higher under non calcareous soil condition than acid soil (Zaman et al., 2015). The number of the branches was higher in $\mathrm{PM}_{3}+\mathrm{CF}_{75}$ treatment for supplying sufficient nutrient throughout the growth period from poultry manure and chemical fertilizers. The number of leaves plant ${ }^{-1}$ increased slowly in earlier days due to establishment and after that the abrupt growth in number of leaves was noticed. The highest number of leaves plant ${ }^{-1}$ was found in $\mathrm{PM}_{3}+\mathrm{CF}_{75}$ under non-calcareous soil condition throughout the growth period. However, it is clear that number of leaves plant ${ }^{-1}$ was higher in the treatment where organic manure and chemical fertilizers (CF) were applied as integrated pattern.

Different doses of organic and inorganic fertilizers significantly influenced the leaf parameters like leaf area. Leaf characteristics viz. leaf length, breadth and area as influenced by different levels of N, P, K and $S$ fertilizers along with the organic manure like CD, PM and VC in acid and non-calcareous soils. Maheshwar (2005) and Khanom et al. (2008) observed enhanced leaf parameters with increased levels of fertilizers. Either sole application of CF or combined application of CF and organic manures like cow dung (CD), PM or vermicompost (VC) have the important roles in increasing the leaf fresh and dry weight of any crop. The biomass yield was maximum due to the application of different organic and inorganic fertilizers both in acid and non-calcareous soil. This is also identical with Angkapradipta et al. (1986) and Nasrin (2008), where the increased biomass production was achieved due to the application of higher levels of $\mathrm{N}$ fertilizers. Aladakatti (2012) reported increased biomass production using different levels of fertilizers. Fallah et al. (2006) carried out an experiment and concluded that use of VC significantly increased the fresh weight of stevia leaves.

\section{Stevioside content}

Results showed that the content of stevioside have been found to be increased significantly with the increase of biomass content up to 60 DAP irrespective of treatments. However, the results further envisaged that the percentage content of stevioside has been recorded highest in the combined application of PM and CF (10.45\%) over that of corresponding sole application of CF and that of control treatment. It was observed that the stevioside content was increased with the increased rate of PM from 3 to $5 \mathrm{t} \mathrm{ha}^{-1}$ along with CF irrespective of growth period. The results are in accordance with the findings of Das and Dang (2010) who found increased amount of stevioside with advanced growth period and highest amount of stevioside in the stevia leaf of the bio-fertilizer treated plant.

The results indicate that the leaf biomass yield and stevioside content in stevia leaf has been markedly increased due to PM application either as single or in combination with CF. However, the overall results suggest that the combined application of PM and CF was always superior as compared to sole application of CF which enhanced significant foliage growth of stevia leaves. In other way, the HPLC study revealed the presence of stevioside in the stevia extract in acidic soil and interestingly, the magnitude of increased stevioside content was higher for stevia extracts collected from treatment $\mathrm{PM}_{5} \mathrm{CF}_{75}$ where combination of both fertilizers were applied and that was due to increased amount of organic carbon and other macro and micronutrient contents in the acidic soil with PM (Das and Dang, 2010). 
The stevioside was accumulated in the leaves throughout the growth period of the stevia and concentrated particularly at the later growth stage may be due to higher leaf area and high net photosynthetic rate. Every physiological indexes of the stevia in the PM amended plant were significantly higher than the CF application. That could be the main reason of higher stevioside content of the PM amendment over that of CF addition. Moreover, poultry manure can promote the over-ground growth, root vigour, leaf net photosynthetic capability and the total glycoside contents in leaf of the stevia (Liu and Shi, 2011).

\section{Conclusion}

The study revealed that PM along with different percentages of chemical fertilizer exerted significant influence on the growth, leaf yield and stevioside content of stevia. The highest values of all the parameters except stevioside content were found from the plant receiving PM @ $3 \mathrm{t} \mathrm{ha}^{-1}$ along with $75 \%$ chemical fertilizer. Stevioside content was increased with higher levels of PM up to $5 \mathrm{t} \mathrm{ha}^{-1}$ along with the advancement of growth period from 30 to 60 DAP. The highest amount of stevioside $(10.45 \%)$ was found in the leaves of the plant that received PM @ $5 \mathrm{t} \mathrm{ha}^{-1}$ along with 75\% CF. Considering all the studied parameters and treatments, it can be concluded that stevia could be cultivated in acid soil applying PM @ $3 \mathrm{tha}^{-1}$ along with $75 \%$ chemical fertilizer for producing higher leaf biomass yield of stevia.

\section{Acknowledgement}

We express our sincere thanks and gratitude to the concerned authority of Bangladesh Agricultural Research Council (BARC), Farmgate, Dhaka for financial support.

\section{References}

Aladakatti, Y.R., Palled, Y.B., Chetti, M.B., Halikatti, S.I., Alagundagi, S.C., Patil, P.L., Patil, V.C. and Janawade, A.D. 2012. Effect of nitrogen, phosphorus and potassium levels on growth and yield of stevia (Stevia rebaudiana Bertoni). Karnataka J. Agri. Sci., 25. 25-29.

Angkapradipta, P., Warsito, T. and Katiman, M. 1986. Manuring of stevia on andosol. Center Agric. Lib. Technol. Dissem. Indonesia 54, 131-137.

Brandle, J.E. and Rosa, N. 1992. Heritability for yield, leaf : stem ratio and stevioside content estimated from a land race cultivar of Stevia rebaudiana. Canadian J. of Plant Sci., 72, 1263-1266.

Das, K. and Dang, R. 2010. Influence of biofertilizers on stevioside content in Stevia rebaudiana grown in acidic soil condition. Archives of Applied Science Research 2, 44-49.

Donalisio, M.G.R., Duarte, F.R., Into, A.J. and Souza, C.J. 1982. Stevia rebaudiana. Agronomic 34, 65-68.

Fallah, A., Ghalavand, V.M. and Khajepour, R. 2006. Effects of blending method of livestock compost with soil and mixing it with chemical compost on yield and parts of yield of seed corn in Khorramabad, Lorestan, Agricultural and Natural Resources Science Magazine, 40, :233-242.

Geuns, J.M. 2004. The safety of stevioside. Laboratory of Functional Biology. KUL euven, Euprint ed., Parkbosstraat 3. 3001. Heverlee, Belgium. pp. 85-127.

Goenadi, D.H. 1983. Water tension and fertilization of Stevia rebaudiana Bertoni on Oxidropudalf soil. Menara perkebunan, Horticulture Abstracts 54, 2882.

Gomez, K.A. and Gomez, A.A. 1984. Statistical Procedures for Agricultural Research. $2^{\text {nd }}$ ed. Wiley, New York, USA.

Hasan, H.M. 2008. Agronomic management practice for the improvement of growth and yield of stevia (Stevia rebaudiana Bert.). MS Thesis, Department of Agronomy, Bangladesh Agricultural University, Mymensingh.

Khan, M.A.R. 2014. Production technology of stevia (stevia rebaudiana) by stem cutting. PhD Thesis, Department of Agronomy, Bangladesh Agricultural University, Mymensingh

Khanom, S. 2007. Growth, leaf yield and nutrient uptake by stevia as influenced by organic and chemical fertilizers grown on various types of soil. MS Thesis, Department of Agricultural Chemistry, Bangladesh Agricultural University, Mymensingh.

Khanom, S., Saha, B.K., Islam, M.T. and Chowdhury, M.A.H. 2008. Influence of organic and inorganic fertilizers on the growth, leaf yield, chlorophyll and protein contents of stevia grown in different types of soil. Progressive Agric. 19 (1): 23-31. 
Kinghorn, A.D. and Soejarto, D.D. 1985. Current status of stevioside as a sweetening agent for human use. In Wagner, H. Hikino, H., and Farnsworth, N.R. (Eds). Economic and medical plant research Academic Press London.

Kolb, N., Herrera, J.L., Ferreyra, D.J. and Uliana, R.F. 2001. Analysis of sweet diterpene glycosides from Stevia rebaudiana: Improved HPLC method. J. of Agri. and Food Chem., 49, 4538-4541.

Kumar, R., Sharma, S. and Prasad, R. 2013. Yield, nutrient uptake and quality of stevia as affected by organic sources of nutrient. Communications in Soil Science and Plant Analysis 44, 3137-3149.

Lee, J.I., Kang, K.H. and Lee, E.U. 1979. Studies on the new sweetening source plant stevia (Stevia rebaudiana) in Kerea. I. Effects of dates of transplanting, taking, cuttings and sowing on the growth characteristics and dry leaf yields of stevia. Korean. Research Report. p. 21.

Liu, X., Ren, G. and Shi, Y. 2011. The effect of organic manure and chemical fertilizer on growth and development of Stevia rebaudiana Bertoni. Dryland Technology Key Laboratory of Shandong Province in Qingdao Agricultural University, Qingdao, 266109, China. 5, 1200-1204.

Maheshwar, H.M. 2005. Effect of different levels of nitrogen and dates of planting on growth and yield of stevia (Stevia rebaudiana Bert.). Dept. of Hort., College Agric., Dharwad University Agric. Sci., Dharwad, p. 55.

Nambiar, K.K.M. 2000. Long-term fertility effects on wheat productivity. Proc. Wheat for non-traditional warm ares, (Saunders. OA. Ed), CIMMYT.1. pp 516-521.

Nasrin, D. 2008. Effect of nitrogen on the growth, yield and nutrient uptake by stevia. MS Thesis, Department of Agricultural Chemistry, Bangladesh Agricultural University, Mymensingh.

Nepovim, A.V.T. 1998. In vitro propagation of stevia rebaudiana plants using multiple shoot culture. Planta Medica 64, 775-776.

Page, A.L., Miller, R.H. and Keeney, D.R. (eds). 1982. Method of Soil Analysis, Part-2 Chemical and Microbiological Properties, $2^{\text {nd }}$ edn., American Society of Agronomy, Inc. Madison, Wisconsin, USA.

Shock, C.C. 1982. Experimental cultivation of Rebaudia's stevia in California. University California, Davis. Agron. Prog. Rep. 122.

Steel, R.G.D., Torrie, J.H. and Dickey, D. 1997. Principles and Procedures of Statistics: A biometrical approach. $3^{\text {rd }}$ Ed. McGraw Hill Book Co. Inc., New York, USA. Pp. 400-428

Warren, J.G., Phillips, S.B., Mullins, G.L., Keahey, D. and Penn, C.J. 2006. Environmental and production consequences of using alum-amended poultry litter as a nutrient source for corn. J. Env. Quality 35, 172-182.

Zaman, M.M., Chowdhury, M.A.H. and Chowdhury, T. 2015. Growth parameters and leaf biomass yield of stevia (Stevia rebaudiana, Bertoni) as influenced by different soil types of Bangladesh. J. Bangladesh Agri. Uni.,13(1): 25-31. 